\title{
Technology Education for National andHuman Capital Development, The Challenge of the Era
}

\section{Adamu Gambo Saulawa}

\author{
Department of Technical Education, College of Science and Technology, Hassan Usman Kaysina Polytechnic
}

\section{Doi:10.5901/jesr.2014.v4n7p92}

\section{Abstract}

For any technological advancement to take place anywhere at any point in the world, technology education is the veritable tool for that. This (Technology education) is always a rule for human capital development in the various economies of the world. Technology education is the primary and fundamental vessed needed by a country to enter the international arena vis-avis economic growth countries must invest necessary resources in education so as to give rise to the skills needed for more rapid growth of the economy. This paper purvey the extent to which education has direct impact on human capital development. The challenge of the era is also discussed with special emphasis on Nigeria's aims and objectives of education conclusion and recommendation were finally made.

Keywords: Technical education, human capital development.

\section{Introduction}

In the attainment of economic development with the respect to human capital all over the world education no doubt has become a farmable ideology. A strategy for achieving rapid economic growth has become an important focus of development and development countries. Countries seek to develop their economies through comprehensive human capital development programmes not only for internal benefit, but most important is for international relevance. To accomplish this task, countries will need to invest substantively in education to ensure that the citizenry have the basic knowledge, skills, competencies and capabilities to effectively and efficiently dominate their environment in order to conform to the world of change

.Globally; most countries have embraced qualitative education as a means of enhancing human capital. Ordinarily, education is a service provided in all countries with many objectives these objectives comprise the skills required for a more rapid economic growth and the provision of basic knowledge to the citizens of the country.

\section{Concept of Development}

Isitoah (2010) defined development as the process and product of the advancement of human abilities and capabilities and to explore, exploit, harness, and utilize his historical, cultural, scientific, institutions and resources in such a manner that brings about the eradication or drastic reduction of the impact of the impact of natural and man-made obstacles or hindrances to fulfilling a vision of a properly ordered just, peaceful, humane, prosperous and progressive society.

The attainment of the highest level of development possible is always the ultimate desire of any nation in the world .their level of development as Developed; Developing or 'underdeveloped'.

\section{What Human Capital is?}

It is pertinent to note that the most valuable of all capital is that investment in human being. What then is human restage capital? Rastogi (2000) stated that human capital is an important input for organization especially for employee's continuous improvement mainly on knowledge, skills and abilities.

Similarly Schultz (1993) defined human capital as a key element in improving a firm assets and employees in order to increase productive as well as sustain competitive advantage.

Human capital Therefore is referred to as processes that relate to training, education and other professional initiative in order to increase the levels of knowledge, skills, abilities, values, and social assets of an employee which will lead to the employee's satisfaction and performance, and eventually on a firm performance? 
In other words in this current technological era firms and organizations optimal performance is hinged on the quality of their employees being foremost enough others.

Human capitals it relates to the society in general and not to firms and organizations only, can be conceptualized as all efforts geared towards training and equipping human with the capabilities to effectively and efficiently dominate their physical and socio-cultural environment so as it improve their lot in life and that of their immediate and for environment

\section{Concept of Education}

Education is the process of acculturation by which the individual is assisted to attain the maximum activation of his potentialities according to the right reason and to achieve there by his self-fulfillment or self-realization. (Okafor 1981) this definition is considered useful because of the link between education and potentialities. In this sense, education is used to develop the potentials of a man in order to actualize his dream which will be beneficial to him in particularly and the society in general.

Fafunwa (1989) define education that has link with human capital as $n$ aggregate of all the processes by means of which an individual develops abilities, skills and other forms of positive behaviors in the society in which he lives it can be deduced from Fafunwa definition, that education is a sum total of various processes geared towards developing the individual, and by implications, his society. Invariably, through the process, product and discipline of education, man is oriented, taught equipped and imbibed with experiences, capabilities, knowledge and techniques to improved his lot and that of his immediate environment, and by this act improves the overall development status of his nation And the world in general.

\section{Aims and Objectives of Education in Nigeria}

The government of the federal Republic of Nigeria first in 1977 and revised in 1981 formulated a national policy on education with aims and objectives clearly stated as follows.

1. The inculcation of the national consciousness and national unity ,

2. The inculcation of the right type of value and attitude for the survival of the individual and the Nigerian society,

3. The training of the mind in the understanding of the world around, and

4. The acquisition of appropriate skills, abilities and competencies both mental and physical as equipment for the individual to live and contribute to the development of his society.

The aims and objectives of the Nigerian national policy on Education as highlighted above clearly provide for the development of the individual, which in turn is expected to have positive effect on the Nigerian economy. It is therefore not out of place to state that if Nigeria must achieve economic growth and acquire the much sought after socio-political and economic leverage in the international community, her National policy on Education must be religiously implemented.

\section{The Relationship between Education and Human Capital}

The link that exists between education and human capital cannot be overemphasized. In fact human capital is dependent on education. It is on the strength of this that Adesina, Fegbongbe and Talabi (1985) define education as tool for the integration of the individual effectively into a society so that he can achieve self-realization, develop national consciousness, promote unity and strive for social, economic, political, scientific, cultural and technological progress.

Human capital therefore catapults a nation's economic growth and further puts such nation in the committee of developed countries that have the well withered to determine the pace of technological advancement globally. Nevertheless, no nation can boast of having a strong base of human capital without the provision of qualitative education. In other words, human capital is an off-shoot of education.

There is no doubt that most nation of the world recognize the fact that education serves as springboard for achieving human capital, which translate into rapid development of the citizens and the countries concerned. Human capital is therefore the knowledge, expertise and skill one accumulate through education and training.

It is not an over-statement to state that education and human capital are inseparable; hence it is a truism that education develops the man, the man using the knowledge, value and skills acquired through education impacts positively on him and the society at large. 
Ezewu (1983) opined that education can be seen to serve society in four ways.

1. It prepares the individuals mind in that he may be internally consistent and harmonious with himself, thus developing the right personality require for living in society.

2. It equips the individual with knowledge, skills and value of the past that are cherished and value by the given society so that they may be preserved from one generation to another.

3. As the individual must live in society to play his role effectively by contributing to the living society, education must equip him with skills, attitude and values which will make him function properly in that society.

4. The future is most uncertain and it has to be planned for so that it may be better than the past and present, education then also equips the individual to bring about useful changes in society.

From the foregoing it can be said that education is the mother of human capital. Thus without education, human capital cannot spring forth, and the development of the man which translates to development of the society cannot be attained.

\section{The Challenge of the ERA}

One of the misfortunes being experienced today in Nigeria vis-à-vis education is the progressive dwindling of fortunes, especially the falling standard of education as reflected in the half baked graduates pouring into the Nigerian labour market. To say that the standard of education has fallen in the country is needed an understatement because it has become completely collapsed and comatose.

The incursion of Nigerian government into the provision of education cannot be separated from political interest. There is not gain saying that education in Nigeria has only received lip-service from the government since independent.

The factors responsible for the dwindling fortunes of education in Nigeria cannot be exhausted here; we will therefore highlight the core of the problems as Capture in Isitoah (2010).

1. Poor finance by both the government and parent

2. Infrastructural decay

3. Lack of interest by parent especially in the monitoring of their children's performance in school and at home

4. Values influences of wealth, get rich very early without any hard work

5. Negative influence of T.V and internet programmes

6. Negative religious influence. Student believes that with prayer all things are possible. So they prefer all night prayers to all night reading. Some pastors even organize special programmes to bless writing materials for students but not to encourage them to read

7. Inadequate supervision both human material

8. Teachers entry qualification and continuous quality enhancement

9. Extraneous variable (dearth of discipline in view of emotions above reasons,etc)

10. Misplaced emphasis on paper qualification rather than on developing technical skills

11. Curriculum review. Nigeria is due for extensive curriculum review to make education functional, environmentally relevant, internationally comparable and positive value laden

12. Examination malpractice and other corrupt practices by students and teachers, the list is inexhaustible.

The crux of the problems confronting education in Nigeria is the government's lack of commitment. The Nigerian government has so far succeeded in formulating lofty education policies, with little or no plan of proper implementation to say the least.

Evan with the glaring fact that education gives rise to human capital, which in turn brings about rapid economic growth, the Nigerian government is unbelievably disengaging from adequate and proper funding of it. Hence, the incessant strikes being witnessed every now and then in our higher institutions, particularly the universities leave much to be desired. With all the problems inherent in the educational sector in Nigeria, specifically the tones being created by the government, development of a strong human capital base that will facilitate rapid economic growth is more or less a mirage.

\section{Recommendation}

It is the opinion of this paper that the following recommendation will bring about qualitative education in Nigeria.

- Adequate founding of education by the Nigerian government, and sincere implementation of educational policies to the letter. 
- Intensive education summit be convened, where all stakeholders should be involved with regard to reviewing the country's education curriculum.

- Multinationals operating in Nigeria should as a matter of law is compelled to contribute substantially to the growth of education, and not skeletal service they are rendering currently.

- Religious bodies should sensitize their member, particularly the student's circle of the need to studies hard and back it with prayers. Rather than the dreadful trend of discarding hard work and relying solely on miracles

\section{Conclusion}

From the foregoing, it is apparent that education is not just a productive; it is the biggest and most reliant of all with respect to human capital development. It is also evident that education is not taken seriously in Nigeria, particularly by the government.

The paper has also outlined what the Nigerian government and other stakeholders can do to see that education in the country is completely resuscitated and revamped for any technological advancement to take place.

\section{References}

Adiotomre, J.E. (1999). History of education.Ughelli: Eregha Publishers. Becker, G.S.(1993).Human capital: A theoretical and empirical analysis with special references to education ( $3^{\text {rd }}$ Ed).Chieage: University of Chicago press.

Ikeke, M.O. and Eko, K. (2008).Eradicating extreme poverty and hunger in Nigeria.

The role of government and the church. A paper presented for publication inthe journal of the school of vocational education, collage of education, warri.

Isitoah, O. (2010). Education and human capital development: the role of theChristian youth. A paper presented at the new Apostolic Youth convention,Nehemiah international schools, Okwokoko.

Kalusi, J.I. (1990).An introduction to philosophy of education. Warri: COEWAPublishers.

Marimuthu, M. Aroliasamy, L, and Ismail, M. (2009). Human capital development andits impact on firm performance: Evidence from development economics. Thejournal of international social Research Volume2/8.

Okafor, F.C. (1981).Philosophy of education and third world perspective. Enugu: StarPublishing Co.

Rastogi, P.N (2002). Sustaining enterprise competitiveness-is human capital theanswer. Human system management. (19(3), 193-203.

Schultz, T.W. (1993). The economic importance of human capital in modernization.Education Economics 1(1), 13-19. 